\title{
COMMUNITY MOVEMENT OF WASTE USE TO KEEP THE IMAGE OF TOURISM INDUSTRY IN GIANYAR
}

\author{
I Gusti Ketut Indra Pranata Darma ${ }^{1}$, Made Ika Kusuma Dewi ${ }^{2}$,Ni Made Rai ${ }^{3}$ \\ (1)(2)(3) Dharma Duta Faculty, Institut Hindu Dharma Negeri Denpasar \\ indra163@yahoo.co.id, dewiikakusuma@gmail.com, kadek.kristina85@.gmail.com
}

\author{
Submitted : 26 February 2020 Revised:24 March 2020 \\ Accepted :2 April 2020
}

\begin{abstract}
ABSTRAK
Berbagai macam aktivitas yang ada di Pulau Bali, menyebabkan seluruh elemen masyarakat bergerak dalam berbagai bidang pekerjaan yang tersedia. Hampir sebagian besar aktivitas masyarakat menimbulkan sampah baik skala rumah tangga maupun skala industri salah satunya di industri pariwisata. Pada industri pariwisata di bali yang merupakan salah satu penopang utama kehidupan masyarakat bali, sampah ini hampir ditemui hampir disemua objek wisata seiring dengan makin masifnya kegiatan pariwisata. Meningkatnya penumpukan sampah ini bukannya tidak disadari oleh pemerintah dan masyarakat, tetapi perlu ditingkatkan gerakan dalam pengelolaan sampah yang ada. Hal ini terlihat dari adanya Peraturan Gubernur Bali nomor 97 tahun 2018 tentang pembatasan timbulan sampah plastik sekali pakai yang menunjukkan bagaimana pemerintah peduli akan permasalah sampah yang sudah lama terjadi selama ini terutamanya dalam menjaga citra pariwisata bali. Meskipun masih cukup tinggi timbulan sampah yang sering ditemui di beberapa tempat. Penelitian ini akan mencari beberapa gerakan masyarakat baik yang terorganisir seperti pada komunitas Trash Hero Indonesia maupun yang belum dalam mengurangi timbulan penggunaan sampah untuk menjaga citra pariwisata bali. Sehingga didapatkan beberapa tindakan alternatif yang mendukung Peraturan Gubernur Bali nomor 97 tahun 2018 yang mampu secara efektif dalam mengurangi resiko pencemaran lingkungan dengan adanya sampah plastik tersebut. Diharapkan tindakan alternatif ini dapat menjaga dan memberikan warisan yang positif bagi generasi berikutnya.
\end{abstract}

Kata Kunci : Citra Pariwisata, Plastik, Sampah

\section{ABSTRACT}

Various kinds of activities that exist on the island of Bali, causing all elements of society to move forward in various fields of work. Most of the community's activities cause garbage both in household scale and industrial scale, one of which is in the tourism industry. In the tourism industry in Bali which is one of the main pillars of the life of the Balinese people, this waste is almost found in almost all tourism objects along with the increasingly massive tourism activities. Increasing the accumulation of waste is not realized by the government and the community, but it needs to be improved in the management of existing waste management. This is evident from the existence of the Bali Governor Regulation number 97 of 2018 concerning restrictions on the generation of disposable plastic waste that shows how the government cares about the long-standing waste problem especially in maintaining the image of Bali tourism. Although it is still quite high, waste generation is often found in several places. This research will look for some well-organized community movements such as the 
I Gusti Ketut Indra Pranata Darma, Made Ika Kusuma Dewi and Ni Made Rai Kristina:

Community Movement of Waste Usage to Maintain The Image of Tourism Industry in

Gianyar

Trash Hero Indonesia community and those who have not reduced the use of waste to maintain the image of Bali tourism. So that there are several alternative actions that support the Bali Governor Regulation number 97 of 2018 which is able to effectively reduce the risk of environmental pollution in the presence of plastic waste. It is hoped that these alternative actions can maintain and provide a positive legacy for the next generation.

Keywords: Waste, Plastic, Tourism Image INTRODUCTION

Bali tourism industry which is currently moving quite massive is a very promising opportunity for the surrounding community, especially people in Gianyar. Tourism based of I Gusti Bagus Rai Utama (2017) is an activity aimed at organizing tourism services, providing or commercializing tourist objects and attractions, tourism facilities businesses and other related businesses in the field. This tourism is a condition of a trip referred to as tourism travel if the trip is done from one place to another, outside the residence of the person used to live (Yoeti, 2003). Drove in the $2015 \mathrm{~s}$, introduced a new era in the world of tourism called Tourism 4.0 (Tourism 4.0). According to the Ministry of Tourism (2019) Tourism 4.0 is a tourism trend that uses big data processing collected from a large number of tourists in achieving personalized travel experiences using modern and high technology. The aim of tourism 4.0 is to develop tourism rapidly with multiplied growth. Where tourists targeted are millennial tourists who have a tendency to be independent and individual behavior.

The development of Tourism 4.0 is starting to be seen from the self-supporting of tourists in finding information about desired tourist destinations, flight ticket reservations and tour packages that are starting to be independent and change with digital media. The rapid development of technology has many benefits for the world of tourism today. If you are able to manage the tourism industry well, then tourists will easily make a visit and are increasingly interested in the tourism industry. Moreover, the tourism industry is one industry that is quite vulnerable to a particular issue, so it needs to be protected from various kinds of global issues that develop in society.

According to I Gusti Bagus Rai Utama (2017) in his book said that there are several things that need to be considered in the development of modern technology today:

1. There is a shift from manual tickets to electronic tickets.

2. Each individual can make their own orders

3. The use of internet technology is increasingly widespread and becomes a medium of information and communication

From these 3 things, it can be seen how significant the role of current technological advances is. Nowadays tourists can move much more freely in determining their desires in a tour without being limited by travel agents and full of information disclosure.

According to Wiwin (2019) tourism is an activity that directly touches and engages the community so that it brings various impacts to the community. This tourism is also able to maintain the relationship between humans and humans as in the application of Tri Hita Karana.

This great opportunity is balanced by the beauty of nature which is already very well known throughout the world. The massive tourism industry is also followed by increasing waste generated by the tourism industry. According to the Bali Partnership agency, the amount of waste in Bali reaches 4.28 tons every day, of which around $11 \%$ flows directly to the sea.

According to Law No. 18 of 2008, waste is a remnant of human daily activities and / or solid natural processes. Traditional waste management, in Bali since the past, has 
I Gusti Ketut Indra Pranata Darma, Made Ika Kusuma Dewi and Ni Made Rai Kristina:

Community Movement of Waste Usage to Maintain The Image of Tourism Industry in

Gianyar

traditionally been known as organic waste management, namely by making waste as food for pigs and as green fertilizer by planting in rice fields (Wardi, 2011). Good waste management can provide benefits to the community in the form of compost, economic benefits in the form of village income, accommdate local labor and other social benefits that are priceless.

\section{LITERATURE REVIEW}

According to Mulasari (2012) waste is an object or material that cannot be used by humans so it is discarded. In the research of Ida Ayu Suarinastuti and I Gst Agung Oka Mahagangga (2016) conducted in monkey forest, management was carried out between organic and organic waste to help reduce the amount of garbage piling up especially plastic waste in the ongoing activities. This is reinforced by the Governor Regulation No. 97 of 2018 concerning the Limitation of Plastic Waste Collection which has become a daily necessity for the community.

According to research from Masjhoer (2018), waste in the tourism business produces from organic and inorganic types. The production process and services provided to tourists require raw materials and produce waste in the end and cannot be avoided. In this process a policy is needed in managing waste from each activity. In the tourism industry, cleanliness is one of the factors that influence the attractiveness of tourist destinations and if maximized it can become an invaluable resource for creative industry movers (Rany Puspita, 2017).

Aside from being an invaluable resource, this waste also has potential hazards. According to Komang Ayu (2008) there is a hazardous waste for health namely B3 waste which can increase mortality and mobility or cause reversible disease or potentially irreversible or severe illness that is recovering.

In reducing waste basically the $3 \mathrm{R}$ principle (Reduce, Reuse, Recycle) is a sequence of steps to manage waste properly. The main priority is Reduce, which is to reduce waste generation, especially plastic waste by carrying shopping bags by himself, using products that can be used repeatedly. Reuse reuse materials that can be used as funds for reuse by making handicrafts or upcycle processes. Recycle recycles waste by melting, chopping, melting or reshaping into new products that generally experience a decrease in quality.

Garbage arising from the tourism industry needs to be a serious concern for the Balinese people, especially the existing tourism actors. The high level of waste generation if not resolved as much as possible in the initial scope will form a negative image for tourists, especially foreign tourists. This negative image began to be voiced by a number of foreign tourists who appeared in many media, especially electronic media and mass media.

According to Hanif et al (2016), destination image is a belief / knowledge about something that can be a destination and what is felt by tourists during a tour.

Development of the image of urban tourism areas requires the development of elements of tourism image development from the most priority to the least priority (Budi et al, 2015). According to the Indonesian Ministry of Trade (2011), image is not only about the brand of a product with a particular tagline. This image is an impression given by someone who comes to a place and also influences others. This image will influence when someone travels. Destination imagery can influence tourists' desires to visit and desires and recommend destinations to other tourists. The concept of destination image where tourism managers and DMOs are one of the important factors in marketing tourist destinations (Maria, 2009). The current image of tourists will be cohesive and ideal about the world that intends to bring tourists to certain destinations and turn tourists into these objects. Destination image is a very important factor for tourists to determine their destination (Sunitha, 2017). According to Echtner and Ritchie (2003), the main 
I Gusti Ketut Indra Pranata Darma, Made Ika Kusuma Dewi and Ni Made Rai Kristina:

Community Movement of Waste Usage to Maintain The Image of Tourism Industry in

Gianyar

purpose of destination imagery is to know tourism habits and plan effective marketing strategies for tourists.

According to Timur (2018), destination image has a mediating effect on service quality and return visits. This destination image strengthens the relationship when added to the model. In improving this negative image of waste, some communities have begun to intensify the reduction of waste generation, especially plastic waste, which has begun to increase. Moreover, there is government support through the Governor Regulation No. 97 of 2018 regarding restrictions on the generation of disposable plastic waste. One community, Trash Hero Indonesia, began routinely carrying out activities to reduce the generation of plastic waste.

The amount of plastic waste that arises will be biodegradable for more than 400 years. Plastic waste is certainly a complex problem for Bali in particular and the earth in general. Careful planning and planning is needed in managing the plastic waste, especially in the Bali tourism industry.

Starting from the smallest tourism industry to the tourist objects in Bali, it requires a wise action that can benefit all parties by paying attention to the environment.

This research is expected to be able to know the existing community movements in the Trash Hero Indonesia community. After learning about community movements, alternative actions can also be taken to reduce the risk of environmental pollution in the presence of plastic waste.

\section{RESEARCH METHOD}

The steps prepared in this activity include:

1. Reveal the actual field conditions

2. Describe the background of research problems in the field, previous research studies to determine the research gap

3. Making a problem statement

4. Identify the concepts contained in the problem to be used in research
5. Conduct a literature study on the image of tourism in Bali at this time

6. Formulate questions

7. Conduct in-depth interviews with informants by using open question data collection techniques, observation, collecting companyowned documentation related to research issues and conducting sound recordings.

8. Record the results of the interview in notes and records

9. Formulating the results of the interview starch

10. Create a category of interviews

11. Give a concept definition to each label name

12. Form a concept

13. Linking one concept to another

14. Constructing a model, which is the relationship between one proposition and another

\section{Data collection technique}

To obtain data, three main techniques will be carried out namely interviews, observation and study of documents. The interview technique that will be adopted will be in-depth interviews with interviewees. If it is still lacking, it will be added to the second resource person.

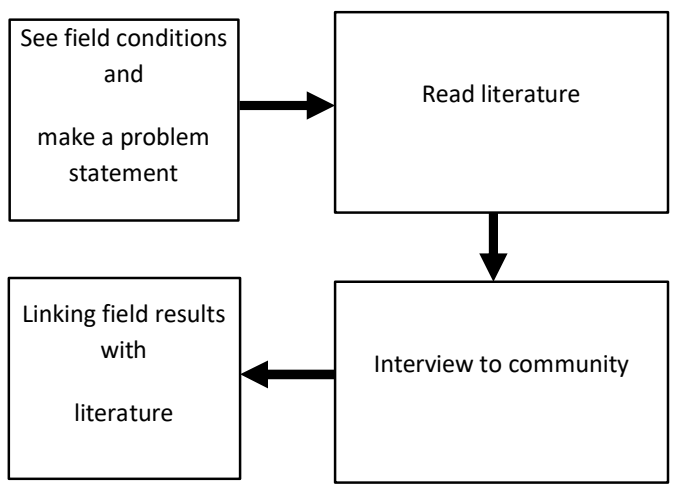

Figure 1. Design Activities

The observations made were located on Saba Gianyar Beach as well as in Tampaksiring Bali Temple to find commensurate information between the 
I Gusti Ketut Indra Pranata Darma, Made Ika Kusuma Dewi and Ni Made Rai Kristina:

Community Movement of Waste Usage to Maintain The Image of Tourism Industry in Gianyar

results of the interviews and the results in the field. Then a document study will be conducted to find out whether the information obtained is similar to the theory or can actually get different types of new information.

In the results of this data collection, a data search was conducted including interviews with the Indonesian Hero Trash Community, as well as conducting a study of research documents in the last 10 years. It was also strengthened by field studies at several observation locations including Saba Beach, Gianyar City, and several places that mainly produce waste especially in the Tourism Industry.

\section{RESULTS AND DISCUSSION Waste in the Tourism Industry}

The tourism industry has many ongoing impacts on the Balinese community in general. Many types of activities that depend on the life of the Tourism Industry. Some tourism industries that currently provide services to tourists and require raw materials, almost certainly produce waste in the end and cannot be avoided (Maasjhoer, 2018). According to a statement from Mr. Wayan Aksara as Chairman of the Indonesian Trash Hero Community, the Tourism Industry is one of the biggest contributors to waste on the island of Bali. Need specific handling for rubbish in Bali, by increasing the handling of rubbish by $10 \%$ it will be able to reduce the presence of rubbish in Bali.

Still according to Mr. Wayan Aksara, this tourism industry is the highest contributor of waste in Bali besides rubbish from Upakara. For example in the Denpasar Code, all types of waste are mixed without sorting. The remnants of upakara waste can be processed into compost first before the residual garbage is brought to the landfill site. $75 \%$ of the available waste goes directly to the landfill without any treatment at the initial level such as in the household or at school. Much of the rubbish currently available is organic and should be treated at an early stage.
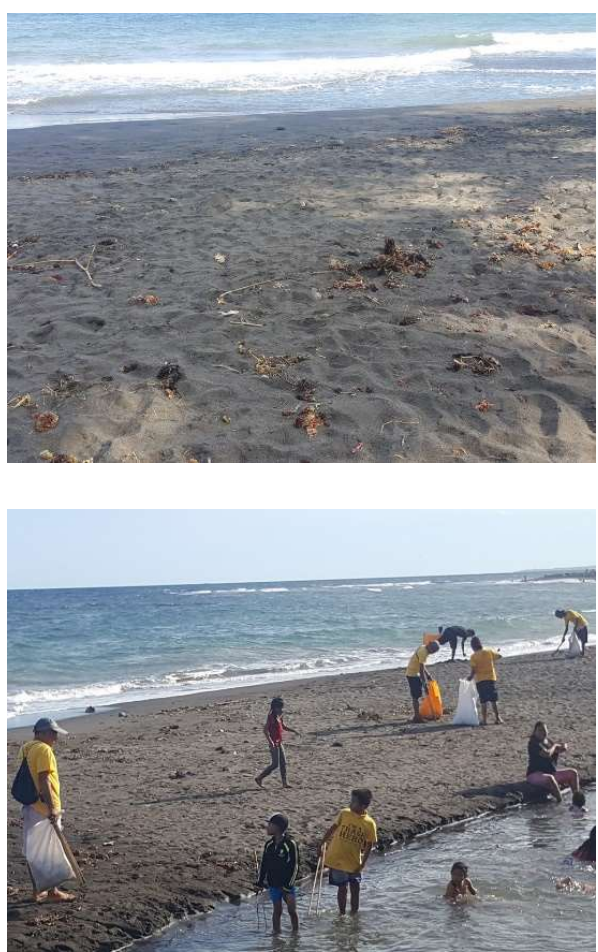

Figure 2. Trash Hero Indonesia clean up Activities (sources: team doc)

Need real action in the form of education as currently done by Trash Hero Indonesia. Such as the formation of Trash Hero Kids outside school hours in the form of educational books by watching and learning in sorting rubbish as well as awarding points for later training in gift giving.

At present, real activities carried out such as clean ups in several places have been routinely available in almost all of Bali. But it is not only such activities that are felt to be necessary. The community places more emphasis on educating each member and the community in managing waste more wisely.

The locations for selecting Trash Hero activities are currently not well managed by the community or government. The location is near the estuaries of garbage. Like in the west coast of Saba in the rainy season. Changes that are currently felt are many changes in waste management 
I Gusti Ketut Indra Pranata Darma, Made Ika Kusuma Dewi and Ni Made Rai Kristina:

Community Movement of Waste Usage to Maintain The Image of Tourism Industry in Gianyar

behavior. This shows the start of attention and mindset for the community.

Efforts to reduce the generation of plastic waste

The high level of plastic waste generation needs to be a particular concern not only for the government but also for all parties. Both the tourism industry, pakraman villages and households. It is feared that the high plastic waste will leave problems for future generations. Some actions that can be taken include.

Conducting education at an early stage at the school and village level of waste management problems in the form of waste segregation. In addition to education in waste segregation, the Trash Hero community also makes an e-book that aims to educate children so that they begin to reduce plastic objects. Starting from the reduction of plastic bags, the use of bottles and replace with refill bottles, to recycle waste.

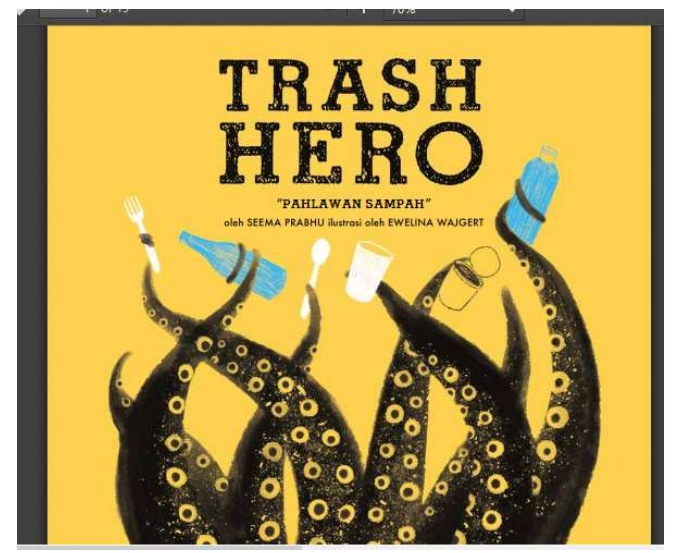

Figure 3. Form of children's education in the form of e-books (sources : trashhero.org)

Educate on the completion of waste at the lowest level, for example in the scope of households before being taken to the Final Disposal Site (TPA) Preparing storage areas such as garbage banks to accommodate various types of waste as conveyed in the research of Ida Ayu Suarinastuti and I Gst Agung Oka Mahagangga (2016) in the monkey forest which is carried out in the management of organic and non-organic waste in helping to reduce the amount of garbage accumulating especially plastic waste on ongoing activities. The utilization of the waste bank was also written by Wardhani and Dwi Harto (2018) who stated that the waste bank is an alternative to encourage citizens to care about waste that can be developed in the regions. This garbage bank has an advantage in community empowerment and provides economic benefits for citizens.

With good waste management such as making a garbage bank will help in maintaining the image of tourism destiasi tourism as revealed by Echtner and Ritchie (2003), whose main purpose of destination image is to know tourism habits and plan effective marketing strategies for tourists. According to Masrida (2017) optimizing the management of Activity Units in the environment in sorting waste is one of the most effective steps in managing waste problems.

An almost similar thing was said by Sunitha (2017), that destination image is a very important factor for tourists to determine their destination. This shows that the destination image is an important point in any tourist destination in Bali. If there is poor waste management on the island of Bali, it will create an unfavorable image in the eyes of the international world. This view is reinforced by Timur (2018), where destination images have an effect on service quality and return visits. This destination image strengthens the relationship when added to the model. So it can affect the decision to return to a tourist destination. Management of a positive destination image requires collaboration from many parties. As in Wiwin's research (2018), communitybased tourism management is a solution in answering various negative issues regarding the management of the tourism industry today. The issue of waste in the tourism industry can be avoided immediately if local communities are involved in managing the problem so as to maintain the image of tourism destinations that are far from garbage. 
I Gusti Ketut Indra Pranata Darma, Made Ika Kusuma Dewi and Ni Made Rai Kristina:

Community Movement of Waste Usage to Maintain The Image of Tourism Industry in

Gianyar

A positive image must be maintained to keep attracting tourists who will visit. Government support such as the Governor Regulation No. 87 of 2018 is a concrete form to reduce the generation of waste, especially plastic waste. One study from Purwaningrum (2016) states that plastic waste in Indonesia amounts to $14 \%$ of the amount of nonorganic waste that cannot yet be treated. The high amount of plastic waste is quite dangerous for the image of tourism destinations.

In addition to maintaining a positive image of tourism, integrated waste management is a form of human concern in maintaining relationships with the surrounding environment. Moreover, the surrounding environment has provided many benefits for humanity. This form of care is an application of Tri Hita Karana that must be maintained to maintain the survival of humans and the earth so that it can be passed on to the next generation.

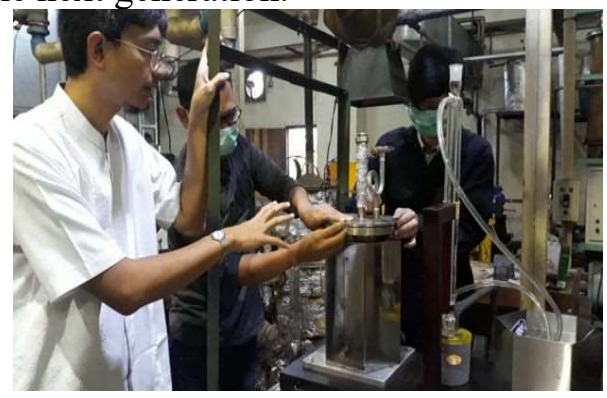

Figure 4. Instant plastic waste processing technology (Sources:okeinfo.net)

At present there is a lot of technology in recycling for waste treatment which is currently still quite high in cost and has been tested on. One of them is a study from Wahyudi et al (2018), which uses a 1 set pyrolysis reactor and uses fuels that are still expensive and environmentally friendly. The use of this technology is currently still managed for industry, and the side effects of combustion using this pyrolysis reactor need to be reviewed. Other research such as that which has been conducted by ITB also uses similar technology, but with almost similar constraints namely regarding the substantial investment costs. It is hoped that in the future the technology can be reduced to the lowest level so that the waste problem in the tourism industry can be overcome.

\section{CONCLUSIONS}

Research on the problem of waste in the image of a tourist destination can be taken several things including:

1. The Trash Hero Indonesia community movement has carried out educational activities to the community in the form of plastic waste collection. In addition to these activities, there are educational activities such as providing education to children about plastic waste sorting and appreciation. This movement is expected to help maintain the image of Bali tourism which is far from organic and non-organic waste

2. The use of a garbage bank is still an alternative solution to reduce the amount of waste generated, but to handle it is still necessary to educate the public on waste reduction as recommended by the Governor of Bali Regulation. The management of this garbage bank must involve the local community, because with this model it will be easier to keep the tourist destination from negative issues about the developing tourism industry.

3. A variety of plastic recycling technologies that are currently available but are still quite high in cost and have not been able to solve the problem instantly. The use of pyrolysis reactor 1 set is one of the instant steps that can be done even though using fuel that is still expensive and environmentally friendly. The use of this technology is currently still managed for industry, and the side effects of combustion using this pyrolysis reactor need to be reviewed.

\section{ACKNOWLEDGEMENT}

The author would like to give highest appreciation to Ni Komang Ayu Adnyani, the Research Team, Mr. Wayan Aksara, the Office of the Environment and all those who 
I Gusti Ketut Indra Pranata Darma, Made Ika Kusuma Dewi and Ni Made Rai Kristina:

Community Movement of Waste Usage to Maintain The Image of Tourism Industry in Gianyar

played a role in the activity / article writing, both in the form of financial support, permits and maximum contribution in helping data collection.

\section{REFERENCES}

Banyai, M. 2009. The Image of Tourism Destinations: A Case of Dracula Tourism. Thesis University of Waterloo: Canada.

Echtner, Charlotte M. 2003. The Meaning and Measurement of Destination Image. The Journal of Tourism Studies Vol. 14, No.1.

Kavunkil Haneef, S. 2017. A Model to Explore the Impact of Tourism Infrastructur on Destination Image for Effective Tourism Marketing.

Hanif, Asya., Kusumawati, Andriani., dan Kholid Mawardi, M. 2016. Pengaruh Citra Destinasi Terhadap Kepuasan Wisatawan Serta Dampaknya Terhadap Loyalitas Wisatawan. Jurnal Administrasi Bisnis Vol. 38 No.1: Universitas Brawijaya Malang.

Indriyo G. 1999. Manajemen Pemasaran, cetakan 5. Penerbit BPFE: Yogyakarta.

Kusumo Wardhani, M. dan Dwi Harto, A. 2018. Studi Komparasi Pengurangan Timbulan Sampah Berbasis Masyarakat Menggunakan Prinsip Bank Sampah di Surabaya, Gresik da Sidoarjo. Jurnal Pamator Vol 11. No.1 April 2018 52-63.

Martins, M. 2015. The tourist Imagery, the Destination Image and the Brand Image. Journal of Tourism and Hospitality Management

Masrida, R. 2017. Kajian Timbulan dan Komposisi Sampah sebagai Dasar Pengelolaan Sampah di Kampus II Universitas Bhayangkara Jakarta Raya. Journal of Env. Engineering \& Waste Management Vol.2 No.2 Oktober 2017 69-78

Maulana Masjhoer, Jussac. 2018. Partisipasi Pelaku Usaha Pariwisata dalam Pengelolaan Sampah di Pantai Pulang Sawal, Kabupaten Gunungkidul,
Yogyakarta. Jurnal Pariwisata Terapan No.2 Vol.2: Yogyakarta.

Mulasari A., Heru H. A., \& Muhadjir N. 2016. Analisis Situasi Permasalahan Sampah Kota Yogyakarta dan Kebijakan Penanggulangannya. Jurnal Kesehatan Masyarakat volume 11 nomor dx.doi.org/10.15294/kemas.vllil.3521

Muljadi, A.J \& Warman, H.Andri. 2016. Kepariwisataan dan Perjalanan. Penerbit: RajaGrafindo Persada Jakarta.

Pakarti Budi et al. 2015. Model Pengembangan Citra Kawasan Pariwisata Berdasarkan Kepuasan Pengunjung: Studi Kasus Jakarta. CoUSD Proceedings:Jakarta. 2015.

Purwaningrum, P. 2016. Upaya Mengurangi Timbulan Sampah Plastik di Lingkungan. JTL Vol 8: Universitas Trisakti Jakarta.

Philip Kotler. 1989. Manajemen Pemasaran: Kunci/Penyelesaian Soal-soal, edisi kelima. Penerbit Erlangga:Jakarta

Puspita Dewi, Rany. 2017. Perancangan Sistem Pengelolaan Sampah untuk Mendukung Industri Kreatif di Daerah Pariwisata. Prosiding Seminar Nasional Unisbank Semarang.

Rambat Lupiyoadi \& A.Hamdani. 2006. Manajemen Pemasaran Jasa, edisi 2. Penerbit Salemba Empat: Jakarta.

Sunyoto, Danang. 2014. Dasar-Dasar Manajemen Pemasaran. Penerbit: Center of Academic Publishing Service

Suarinastuti, Ida Ayu dan Oka Mahagangga, I Gusti Agung. 2016. Pengelolaan Sampah di Daya Tarik Wisata Wana/Monkey Forest, Desa Padantegal, Ubud. Jurnal Destinasi Pariwisata Vol. 4 No.2 :Universitas Udayana.

Timur, Beybala. 2018. Service Quality, Destination Image and Revisit Intention Relation ' ships at Thermal Tourism Businesses. Journal of Gastronomy Hospitality and Travel. 
I Gusti Ketut Indra Pranata Darma, Made Ika Kusuma Dewi and Ni Made Rai Kristina: Community Movement of Waste Usage to Maintain The Image of Tourism Industry in Gianyar

Utama, I Gusti Bagus Rai. 2017. Pemasaran Pariwisata. Yogyakarta: Penerbit Andi

Wahyudi, J., Prayitno, H.T., dan Astuti, A.D. 2018. Pemanfaatan Limbah Plastik sebagai Bahan Baku Pembuatan Bahan Bahan Bakar Alternatif. Jurnal Litbang Vol. XIV. No.1 Juni 2018 58-67

Wardi, I Nyoman. 2011. Pengelolaan Sampah Berbasis Sosial Budaya: Upaya mengatasi masalah lingkungan di Bali. Jurnal Bumi Lestari Volume 11 No.1: Bali. 2011.

William J.Stanton, Michael J.Etzel \& Bruce J. Walker. 1994. Dasar-dasar Manajemen Pemasaran, cetakan 1. Penerbit Mandar Maju: Bandung.

Wiwin, I W. 2019. Faktor Sukses dalam Pengembangan Wisata Pedesaan. Jurnal Pariwisata Budaya Vol 4, No. 2 Tahun 2019.

Wiwin, I W. 2018. Community Based Tourism Dalam Pengembangan Pariwisata Bali. Jurnal Pariwisata Budaya Vol 3, No. 1 Tahun 2018.

Kementrian Perdagangan RI. Membangun "Nation Branding". 2011. Kementrian Perdagangan RI.

---, Undang-Undang No. 18 Tahun 2008 tentang Pengelolaan Sampah

---, Undang-Undang No. 10 Tahun 2009 tentang Kepariwisataan 